\title{
The Commerce Clause Limitation on the Power To Condemn a Relocating Business
}

\author{
Edward P. Lazarus
}

In light of recent Supreme Court decisions expanding the constitutional use of the sovereign power of eminent domain, local authorities are now considering the use of eminent domain in previously uncontemplated contexts. Specifically, local governments are with increasing frequency threatening to condemn businesses that are on the verge of relocation. This Note argues that such takings would violate the Constitution. Neither the payment of just compensation nor any inherent attribute of the taking power can insulate these condemnations from the commerce clause proscription against local actions that burden interstate commerce.

\section{Condemning a Relocating Business}

On June 21, 1982, the Supreme Court of California sanctioned the use of eminent domain power to condemn a relocating business. ${ }^{1}$ Reversing a summary judgment ruling against the City of Oakland in its attempt to condemn the relocating Oakland Raiders football team, the California Court approved two emerging trends in the jurisprudence of eminent domain: first, that intangible property such as contract rights, franchises, patents, goodwill, and other incorporeals are as susceptible to condemnation as tangible or real property; ${ }^{2}$ and second, that local legislatures enjoy broad discretion in determining what public interests are sufficient to meet the U.S. Constitution's "public use" limitation on the taking of private property. ${ }^{3}$

1. City of Oakland v. Oakland Raiders, 32 Cal. 3d 60, 646 P.2d 835, 183 Cal. Rptr. 673 (1982).

2. Here the Court merely recognized what the U.S. Supreme Court had already largely established. See, e.g., Kimball Laundry Co. v. United States, 338 U.S. 1 (1949) (upholding taking of trade routes belonging to laundry service); West River Bridge Co. v. Dix, 47 U.S. (6 How.) 507 (1848) (holding that exercise of eminent domain over contract rights does not violate contract clause).

3. Soon after Oakland Raiders, the United States Supreme Court articulated what had already become its de facto policy toward legislative determinations of public use: "[W]hen the legislature has spoken, the public interest has been declared in terms well-nigh conclusive," Hawaii Hous. Auth. v. Midkiff, 467 U.S. 229, 239 (1984) (quoting Berman v. Parker, 348 U.S. 26, 32 (1954)) (upholding Hawaii land reform statute by which private estates were divided up for benefit of non-landowning public); see also Ruckelshaus v. Monsanto Co., 467 U.S. 986, 1014-16 (1984) (reaffirming broad legislative discretion to determine public use). Since heretofore the "public use" requirement was the only constitutional limit on the power of eminent domain (except the compensation requirement), the 
More specifically, the court rejected the Raiders' argument that the city's power to condemn intangible property did not extend to the taking of a going concern. ${ }^{4}$ Moreover, the Court held that the continued presence of a sports team perpetuated a variety of community values (including civic pride, community enjoyment, and local economic gain) sufficient to constitute the legitimate public use required for the exercise of the taking power. ${ }^{\mathrm{s}}$

Midkiff case, and its theoretical forebears, see, e.g., Berman, 348 U.S. 26, naturally raise the question of whether any meaningful limits remain on a legislature's power to appropriate private property in exchange for compensation. See, e.g., Note, Public Use in Eminent Domain: Are There Limits After Oakland Raiders and Poletown?, 20 CAL. W.L. REv. 82 (1983); Note, A Final Requiem for the Public Use Limitation on Eminent Domain, 60 Notre Dame L. Rev. 388 (1985); see also R. EPstein, Takings: Private: Property and the Power of Eminent Domain (1985) (arguing for strict limits on legislative power to appropriate property rights).

In Midkiff, the Supreme Court did not wholly abdicate the judicial responsibility to scrutinize the legislative purposes behind condemnations: "To be sure . . . 'one person's property may not be taken for the benefit of another private person without a justifying public purpose, even though compensation be paid." " 467 U.S. at 241 (quoting Thompson v. Consolidated Gas Corp., 300 U.S. 55, 80 (1930)). Protectionist condemnations do bear some resemblance to this prohibited private eminent domain. In most cases, government ownership upon condemnation of a business would be merely a temporary incident to ultimate private entrepreneurial or worker control. In addition, while in the ordinary eminent domain case the state takes private property and converts that property to a new and purportedly higher use, in the case of a relocating business, the state would simply take the property and turn it over to private interests in precisely the same form and for precisely the same use as under the original owner. But see 2A Nichois' THE LAw of EMINent Domain \$ 7.49[1][b] (J. Sackman rev. 3d ed. 1981) [hereinafter Nichots] (preservation of historic property represents valid public use). In any event, protectionist takings would almost certainly pass the current public use test. Courts have been strikingly reluctant to invalidate takings, even those closely tied to private interests. See, e.g., Poletown Neighborhood Council v. City of Detroit, 410 Mich. 616, 304 N.W.2d 454 (1981). Though not especially implicated in the business relocation context, the Poletown case (which not only arrayed General Motors against the residents of an impoverished immigrant neighborhood, but also involved the Michigan "quick take" statute under which prospective condemnees had little opportunity to organize politically) suggests that courts might restore some limits on the takings power by giving more exacting consideration to the procedural aspects of condemnations. $C f$. Fullilove v. Klutznick, 448 U.S. 448, 551 (1980) (Stevens, J., dissenting) (judicial review considers "procedural character of the decision-making process"); Sunstein, Naked Preferences and the Constitution, 84 Colum. L. Rev. 1689 (1985) (reading public use limitation to require greater legislative justification than simply majoritarian preference).

4. "Intangible property, such as . . patent rights, franchises, charters or any other form of contract are within the scope of [eminent domain] as fully as land or tangible property," Oakland Raiders, 32 Cal. 3d at 67, 646 P.2d at 839, 183 Cal. Rptr. at 677 (1982) (quoting 1 Nichoss, supra note 3 , at $2.1[2])$.

5. The condemnation of going concerns, whether sports teams or steel mills, sets in high relief the central analytic question of takings jurisprudence: Can courts develop coherent standards for scrutinizing the exercise of eminent domain power without dramatically curtailing the legislature's ability to promote its vision of the public welfare? Put another way, although sanctioning the condemnation of a sports franchise may seem like a radical extension of takings jurisprudence, the courts have yet to create a standard of review that would preserve a state's power to condemn slums for urban renewal yet would prevent Oakland from taking the Raiders. See, e.g., Dunham, Griggs v. Allegheny County in Perspective: Thirty Years of Supreme Court Expropriation Law, 1962 SuP. CT. REv. 63, 65-67 (recounting decline of public use doctrine); Comment, Res Non Protest Peccare??? The Decline and Fall of the Public Use Limitation on Eminent Domain, 76 Drck. L. Rev. 266 (1972) (proposing public oversight and operation as test for public use). Not all commentators would mourn such a radical retrenchment of governmental authority, see R. EPSTEIN, supra note 3 , but while this Note seeks some check on state power to condemn property, it locates that check outside of the takings clause itself precisely to avoid falling down the slippery slope of public use jurisprudence into libertar- 
In sum, the Raiders case established a legal foundation for the condemnation of business enterprises for no reason other than to prevent relocation. ${ }^{6}$ The Oakland precedent has already prompted Baltimore to bring condemnation proceedings against the Baltimore Colts football team after that team fled to Indianapolis in the middle of the night. ${ }^{7}$

By far the more economically significant application of the Oakland ruling, however, has occurred not in the sports world but in the industrial context, where states suffering industrial dislocation have begun to consider eminent domain as a way of keeping business at home and local economies alive. A national sample of 12,063 plants indicated that $12.1 \%$ relocated in the 1970 's, principally from the northeast to the sunbelt. ${ }^{8}$ In response, New Bedford, Chicago, Youngstown, Pittsburgh, Boston, and smaller municipalities throughout the northeast have threatened local industries with condemnations rather than risk plant closings and reloca-

ian notions about the appropriate relationship between government and private property.

Justice Bird, in her concurring and dissenting opinion in Oakland Raiders, balked at the "creeping statism" involved in the condemnation of a going concern simply on account of the owner's intention to relocate: "II] a rock concert impressario, after some years producing concerts in a municipal stadium, decides to move his productions to another city, may the city condemn his business?" 32 Cal. 3d at 77, 646 P.2d at 846, 183 Cal. Rptr. at 683-84 (1982). Similarly, could New York condemn Dwight Gooden's employment contract if the Mets traded him? Despite these concerns, however, Justice Bird concluded that, "in the absence of a legislative bar to [this] use of eminent domain . . . there appears to be no ground for judicial intervention." Id. In some sense, Justice Bird's acquiescence underscores the difficulty of resolving within the framework of takings jurisprudence the jurisdictional and liberty problems associated with the condemnation of intangible property or personal contracts. See Note, Jurisdictional Limitations on Intangible Property in Eminent Domain: Focus on the Indianapolis Colts, 60 IND. L. REv. 389 (1984) (arguing for jurisdictional rule locating intangible property at owner's domicile); see also infra note 86.

6. After remand, the California Court of Appeals ruled that the taking of the Oakland Raiders violated the commerce clause, 174 Cal. App. 3d 414, 220 Cal. Rptr. 153 (1985). In an opinion virtually devoid of analysis, the court held that the relocation of the Raiders franchise, although intrastate, implicated the welfare of the entire National Football League and consequently raised issues of interstate commercial law. The court's resolution of the commerce clause issue rested on two grounds, both only marginally applicable to the industrial plant relocations with which this Note is principally concerned. First, the court found that the football franchise system requires "uniform national regulation," making it especially susceptible to commerce clause scrutiny. Second, the court employed a balancing test weighing the local interest involved against the burden to commerce. Although sports teams may provide considerable psychic benefits to a city, condemnations of industrial plants will generally involve far weightier local concerns than sports team relocations.

7. Indianapolis Colts v. Mayor \& City Council of Baltimore, 741 F.2d 954 (7th Gir. 1984). Although the Colts litigation was settled before trial, Baltimore's attempted condemnation presented precisely the issue addressed in this Note: Can a municipality take a business relocating out-of-state? Before settlement, the Colts had raised a tricky jurisdictional question underscoring how easily this particular exercise of eminent domain power implicates out-of-state interests. Since the Colts had abandoned their Baltimore headquarters and had hastily set up shop in Indiana prior to the actual taking, a threshold question arose as to where the franchise was legally located. Whether under these unusual circumstances Baltimore could have condemned property in some sense located in another state remains unresolved. See 1 Nichols, supra note 3, at $\$ 2.12$ ("There is one limitation on the power of eminent domain which depends on no express constitutional provisien. The powers of a sovereign State, however vast in their character and searching in their extent, are inherently limited to the subjects within the jurisdiction of the state. . . .").

8. See Note, The Use of Eminent Domain To Prevent an Industrial Plant Shutdown: The Next Step in an Expanding Power? 49 AL.B. L. Rev. 95, 97 n.11 (1984) [hereinafter The Next Step]. 
tions. No takings have occurred yet, but in New Bedford and Pittsburgh the threat of condemnation persuaded Morse Cutting Tools and Nabisco, respectively, not to close factories and relocate assets. ${ }^{9}$ In part to provide time for the third-party or subsidized worker buyouts that would follow condemnations, municipalities in over twenty states have enacted or are considering ordinances requiring industries to provide long advance notice of planned closings and relocations. ${ }^{10}$

Using tax abatements, municipal bond offerings, low-interest loans, and other lures, the states are engaged in a fierce competition for business and industry. Whether states can add protectionist condemnations to their competitive arsenals is a question of profound import for industrial policy.11 To date, the courts have placed no constitutional limitations on the "carrots" with which states entice industries to relocate. ${ }^{12}$ But as this Note demonstrates, unless the Supreme Court abandons its current reading of

9. The New Bedford case is the most celebrated to date. There, in the spring and summer of 1984, a coalition of state officials, community representatives, and threatened workers banded together in an attempt to keep the multinational Gulf \& Western Corporation from closing down and relocating the assets of its subsidiary, the Morse Cutting Tool Company, the nation's first twist drill manufacturer. After being threatened with condemnation, Gulf \& Western first extended its original closing date and then eventually sold the plant to a community-approved owner. N.Y. Times, June 5, 1985, at $\mathrm{Al}$, col. 1.

More recently, community organizers and workers at the Colonial Provisions Company in Boston attempted to stop the closing and relocation of a local meat-packing plant by convincing city officials to condemn it. The city council ultimately decided against taking the plant, sparking a series of public protests. Privately, organizers of the proposed condemnation claimed that if a plant closing notification law had been in effect, allowing for more and better lobbying, they would have succeeded. Boston Globe, Mar. 9, 1986, at 40, col. 2.

10. See Comment, National, State and Local Perspectives on the Regulation of Business Dislocations: Smaller Mfrs. Council v. City of Pittsburgh, 45 U. PITT. L. Rev. 439 (1984) (discussing legality of Pittsburgh's "Plant Closing and Notification Ordinance"). Indeed, pre-notification is the focus of considerable tension between labor and management in the so-called sunset industries. See supra note 9.

11. Given the acute recession of the early 1980 's, the severe depression that still plagues the country's basic industries, and the shrinking share that American products command in world markets, economic analysts agree that the nation's economy is in a state of transition. A central issue for economists of every political bent is the extent to which the government should actively protect troubled industries (such as steel) from both irternational competition and internal dislocation. Protectionist condemnations are locally imposed obstacles to the kind of fundamental reordering of the American economy that many commentators consider imperative if the nation's standard of living is to be maintained over the long term. See, e.g., R. Reich, The Next American Frontier (1983); L. Thurow, The Zero Sum Society (1980); Rohatyn, Time for a Change, N.Y. Rev. Books, Aug. 18, 1983, at 16, col. 2.

12. For an excellent analysis of the difference between regulatory incentives (such as tax abatements) and coercive exploitations (such as embargoes), see Levmore, Interstate Exploitation and Judicial Intervention, 69 VA. L. Rev. 563 (1983). According to Professor Levmore's reading of the dormant commerce clause, exploitations (defined as those regulations which threaten to diminish commerce by creating monopoly or monopsony power in the home state) generally have been and should be struck down. Mere interferences (regulations which pose no monopoly threat) generally have been and should be upheld. Id. at 570-75. Under Levmore's analysis, protectionist condemnations would fit squarely into the disfavored category of potentially exploitative state action. Protectionist condemnations pose the danger that "an aggressor state [could] exploit a unique advantage it enjoys because of its location, history or resources." Id. at 565. 
the commerce clause, the "stick" of protectionist condemnations cannot survive. The use of local eminent domain power to prevent industrial relocation violates the Constitution.

\section{The Commerce Clause Limitation}

Although the plain language of the commerce clause is simply an affirmative grant of power to Congress, ${ }^{13}$ since the mid-nineteenth century the Court has interpreted it to include a "dormant" prohibition of state regulation of interstate commerce. ${ }^{14}$ Recalling that economic warfare between the states under the Articles of Confederation was a principal catalyst for the Constitutional Convention, ${ }^{18}$ the judiciary has resisted the "economic Balkanization" that naturally arises in difficult economic times. ${ }^{10}$ Following a general rule that "a state may not promote its own economic advantage by the curtailment or burdening of interstate commerce,"17 the Court has often used the dormant commerce clause to invalidate local protectionist measures. ${ }^{18}$

The current rule for applying the dormant commerce clause derives

13. U.S. ConST. art. I, $\S 8$, cl. 3 reads in part, "Congress shall have the Power . . . to regulate Commerce ... among the several States."

14. The dormant commerce clause is one of "the great silences of the Constitution." H.P. Hood \& Sons v. Du Mond, 336 U.S. 525, 535 (1949). As early as Sturges v. Crowninshield, 17 U.S. (4 Wheat.) $122,143(1819)$, the Court recognized that in some cases the commerce clause deprives states of any authority to affect interstate commerce "as if they had been expressly forbidden to act."

Since its original application, the Court has on numerous occasions, and at times inconsistently, redefined and restated the scope of the dormant commerce clause. In some cases, the Court has analyzed state regulation according to whether its effect on interstate commerce was "direct" or "incidental." See, e.g., Shafer v. Farmers Grain Co., 268 U.S. 189 (1925). In other cases, the Court has focused on whether the object of regulation was essentially "local" or "national" in character. See, e.g., Cooley v. Board of Wardens, 53 U.S. (12 How.) 299 (1851) (upholding a Pennsylvania pilotage requirement for ferries). These labels, however, proved largely conclusory and have for the most part been abandoned. The Court's modern approach to settling conflicts between legitimate local concerns and the proscriptions of the commerce clause has been to apply a balancing formula entailing "a consideration of all the facts and circumstances, such as the nature of the regulation, its function, the character of the business involved and the actual effect on the flow of commerce." DiSanto v. Pennsylvania, 273 U.S. 34, 44 (1927) (Stone, J., dissenting). For a good history of dormant commerce clause jurisprudence, see Regulation, Federalism and Interstate Commerce 17-45 (A. Tarlock ed. 1981).

15. See Abel, The Commerce Clause in the Constitutional Convention, 25 MinN. L. Rev. 432 (1941).

16. See Hughes v. Oklahoma, 441 U.S. 322,325 (1979).

17. H.P. Hood \& Sons v. Du Mond, 336 U.S. 525, 532 (1949) (striking down New York milk licensing scheme); see also, e.g., Baldwin v. G.A.F. Seelig, Inc., 294 U.S. 511, 527 (1935) (The entire Constitution was "framed upon the theory that the people of the several states must sink or swim together, and that in the long run prosperity is in union and not division. . . . What is ultimate is that one state in its dealing with another may not place itself in a position of economic isolation."); South Pac. Co. v. Arizona, 325 U.S. 761 (1945) (striking down Arizona law limiting number of freight cars a train could pull).

18. See, e.g., Hughes v. Oklahoma, 441 U.S. 322 (1979); Hunt v. Washington State Apple Advertising Comm'n, 432 U.S. 333 (1977); Dean Milk Co. v. Madison, 340 U.S. 349 (1951). 
from Pike v. Bruce Church, Inc.:" "Where a statute regulates evenhandedly to effectuate a legitimate local public interest, and its effects on commerce are only incidental, it will be upheld unless the burden imposed on such commerce is clearly excessive in relation to the putative local benefits."20

Although not an exercise in absolutes, ${ }^{21}$ the Pike test incorporates a threshold test prohibiting state actions that discriminate against out-ofstate interests (are not evenhanded) or which affect commerce directly (are not incidental). ${ }^{22}$ In applying the Pike test, the Court has allowed states some discretion when they legislate in furtherance of legitimate public interests such as local health and safety, and where the effect on commerce is secondary and unavoidable. ${ }^{23}$ But the Court has consistently invalidated state statutes which either in purpose or in primary effect are tantamount to economic regulation for the benefit of the home state at the expense of out-of-state interests. ${ }^{24}$ In such cases, the Court has not reached the balancing aspect of the Pike test by which the burden on commerce is measured against the local interest. Rather, the Court has adopted a "virtually per se rule of invalidity."25

19. 397 U.S. 137 (1970) (striking down Arizona statute requiring all cantaloupes grown locally be packaged in state).

20. Id. at 142 .

21. It is difficult to discern exactly what the Court means when it claims to balance. In none of the cases does the Court attempt to quantify the local interest or the burden to commerce in order to compare them. As one commerce clause expert has summarized the principle underlying the Court's actual balancing procedure, "The States may interfere with interstate commerce, but not very much." Black, Perspectives on the American Common Market, in Regulation, Federalism and INTERstate Commerce, supra note 14, at 62 (quoting Thomas Reed Powell). In any case, protectionist condemnations would fall within the class of cases in which the Court has specifically eschewed a balancing approach. See infra notes 23-40 and accompanying text.

22. See, e.g., Edgar v. Mite Corp., 457 U.S. 624 (1982) (striking down Illinois takeover statute as directly affecting commerce); City of Philadelphia v. New Jersey, 437 U.S. 617 (1978) (striking down New Jersey waste importation regulation as discriminatory). As one commentator has nicely characterized it, the Pike formulation is "a contingent balancing test" under which every challenged statute must pass a three-pronged threshold scrutiny into the legitimacy of the local interest involved, the statute's evenhandedness, and the nature of its effect on interstate commerce. Blasi, Constitutional Limitations on the Power of States To Regulate the Movement of Goods in Interstate Commerce, in 1 Courts and Free Markets: Perspectives From the United States and Europe 176 (T. Sandalow \& E. Stein eds. 1982).

23. See, e.g., Minnesota v. Clover Leaf Creamery Co., 449 U.S. 456 (1981) (upholding Minnesota packaging law); Exxon Corp. v. Governor of Md., 437 U.S. 117 (1978) (upholding regulation of gasoline retailers); Raymond Motor Transp. v Rice, 434 U.S. 429 (1978) (striking down Wisconsin truck length law); Hunt v. Washington State Apple Advertising Comm'n, 432 U.S. 333 (1977) (striking down North Carolina apple labelling law); Southern Pac. Co. v. Arizona, 325 U.S. at 761 (1945) (striking down Arizona train length limit).

24. See, e.g., Hughes v. Oklahoma, 441 U.S. 322 (1979); City of Philadelphia v. New Jersey, 437 U.S. 617 (1978); Exxon Corp. v. Governor of Md., 437 U.S. 117 (1978); Huron Portland Cement Co. v. City of Detroit, 362 U.S. 440 (1960); see also L. TRIBE, Constrrutional. Law $\$ 6.9$ (1976).

25. Pike v. Bruce Church, Inc., 397 U.S. at 145 (emphasis omitted); see O'Fallon, The Commerce Clause: $A$ Theoretical Comment, 61 ORE. L. Rev. 395, 411 (1982) ("The Court actually disposes of most cases on the grounds of discrimination or an illegitimate local interest. Rarely does the Court balance state against national interest." (citation omitted)); Regan, The Supreme Court and State 
Although the Court has not addressed the problem of protectionist condemnations, it has applied this per se rule in two analogous situations: first, to state capture statutes which pressure out-of-state industries to relocate within the regulating state; ${ }^{26}$ and second, to state embargo statutes which prevent the exportation of natural resources. ${ }^{27}$ Both of these strands of commerce clause jurisprudence argue convincingly for a constitutional proscription against protectionist condemnations.

\section{A. Capture Statutes}

In unbroken precedent, most recently affirmed in Pike, the Court has struck down state regulations that sought to capture out-of-state economic interests. In Foster-Fountain Packing Co. v. Haydel, ${ }^{28}$ the Court invalidated a Louisiana statute prohibiting the export of locally caught shrimp from which the heads and shells had not been removed, thus requiring that out-of-state processing be performed in state. In Toomer $v$. Witsell, ${ }^{29}$ the Court invalidated a similar South Carolina statute requiring shrimp to be packaged and stamped in state. ${ }^{30}$ In Pike, the Court frustrated Arizona's attempt to have all locally grown cantaloupe packaged in state. The Court found an identical flaw in each of these regulating schemes. Each ran afoul of the Court's clear warning that it "views with particular suspicion state statutes requiring business operations to be performed in the home state that could more efficiently be performed elsewhere. . . . This particular burden to commerce has been declared virtually per se illegal."s1

Condemnations that quarantine industries within state borders are essentially the mirror image of the regulatory schemes struck down in Foster-Fountain, Toomer, and Pike. The challenged regulations coerced industry into a state; eminent domain prevents industry from leaving. Their common attempt to gain an economic advantage for the home state that would not otherwise exist makes both types of state action particularly suspect under the commerce clause. ${ }^{32}$ This sort of direct economic manip-

Protectionism: Making Sense of the Dormant Commerce Clause, 84 MiCH. L. Rev. 1091, 1209-33 (1986) (Court does not balance in "movement-of-goods cases, but rather searches for protectionist purpose"); see also infra notes 26-33 and accompanying text.

26. See, e.g., Pike v. Bruce Church, Inc., 397 U.S. 137 (1970).

27. See, e.g., Foster-Fountain Packing Co. v. Haydel, 278 U.S. 1 (1928).

28. Id.

29. 334 U.S. 385 (1947).

30. In Dean Milk Co. v. Madison, 340 U.S. 349 (1951), the Court invalidated a local ordinance requiring that dairy products be pasteurized and bottled within a five mile radius of Madison's Capitol Square. In apparent deference to the perishable nature of the commerce involved, before striking down the law as a classic capture statute, the Court did consider whether any reasonable alternatives existed for protecting local health and safety. Id. at 354.

31. Pike, 397 U.S. at 145 (emphasis omitted).

32. See Levmore, supra note 12, at 591-92 (quarantines may create problem of monopoly power). 
ulation strikes at the core of the commerce clause's prohibition of economic warfare among the states. ${ }^{33}$

\section{B. Embargo Statutes}

A second line of commerce clause cases invalidating state embargoes on the movement of commerce across state lines also demonstrates that protectionist condemnations offend the commerce clause. The crux of these embargo cases is the Court's resolve that individual states do not have the power to protect economic advantages, natural or man-made, from slipping away to other states. "Each state," the Court recently reiterated, "is made the greater by a division of its resources, natural and created, with every other state." ${ }^{\text {"s4 }}$ On this basis, the Court has, for example, struck down state statutes prohibiting the interstate transportation of minnows or the free flow of coal and natural gas beyond state borders. ${ }^{35}$

As with the capture statutes, in applying the Pike test to embargoes, the Court has eschewed a balancing approach and instead has adopted the "virtually per se rule"s6 of invalidity. ${ }^{37}$ As the Court emphasized in a

33. Although Justice Stewart invokes efficiency as his rationale in Pike, neither private owners nor states necessarily make efficient choices of location. See infra Section IV. As many of the Court's other commerce clause decisions illustrate, the Constitution does not mandate perfectly efficient outcomes. States can, for example, establish potentially inefficient subsidy programs, even ones that adversely affect out-of-state interests, if their actions fall within the market participant exception to dormant commerce clause scrutiny. See, e.g., Hughes v. Alexandria Scrap Corp., 426 U.S. 794 (1976); see also Levmore, supra note 12, at 577-89. A better vision of the dormant commerce clause combines notions of market efficiency, political representation, and local competence to legislate on matters affecting national interests. See Sunstein, supra note 3, at 1705-08 (commerce clause protects against naked majoritarian preferences); Tushnet, Rethinking the Dormant Commerce Clause, 1979 Wis. L. REv. 125 (judicial review appropriate when some affected interest not represented in political process); Dowling, Interstate Commerce and State Power, 27 VA. L. REv. 1, 20 (1940) ("Congressional negative will be presumed . . . against state action which . . . constitutes unreasonable interference with national interests"). See generally J. EL.Y, DemocracY and DistRust (1980) (arguing for process-based system of constitutional analysis). States are not the proper unit to be making choices affecting the national market for business location, especially when proposed regulations will have a discriminatory effect on out-of-state interests. The Constitution, through the commerce clause, reserves that role for Congress.

34. See, e.g., City of Philadelphia v. New Jersey, 437 U.S. 617, 623 (1978) ("The opinions of the Court through the years have reflected an alertness to the evils of 'economic isolation'. . . while at the same time recognizing that incidental burdens on interstate commerce may be unavoidable when a state legislates to safeguard the health and safety of its people.").

Even critics of the dormant commerce clause would strike down this type of discriminatory state action-although they would do so under a reinterpretation of other constitutional provisions, principally the privileges and immunities clause. See Eule, Laying the Dormant Commerce Clause to Rest, 91 YALE L.J. 425 (1982)

35. City of Philadelphia, 437 U.S. at 627.

36. Pike, 397 U.S. at 145 (emphasis omitted).

37. See, e.g., Pennsylvania v. West Virginia, 262 U.S. 553 (1923) (striking down legislation ob. structing free flow of coal out-of-state); Oklahoma v. Kansas Natural Gas, 221 U.S. 229 (1911) (striking down limits on natural gas exportation); City of Philadelphia, 437 U.S. at 627 ("A state is without power to prevent privately owned articles of trade from being shipped and sold in interstate commerce on the ground that they are required to satisfy local demands or because they are needed by the people of the State."); Foster-Fountain, 278 U.S. at 10 (same). 
recent embargo case, "the clearest example of [invalid] legislation is a law that overtly blocks the flow of commerce at a state's borders." ${ }^{38}$ Such parochial legislation, in which "the State has overtly moved to slow or freeze the flow of commerce,"39 is impermissible under the commerce clause. States cannot isolate themselves from the national economy-whatever the local benefits involved. ${ }^{40}$

Industries not only produce articles of commerce, they are themselves articles of commerce. Much like the minnows in the streams or the natural gas in the trucks and pipelines, industries and the jobs they create are bought, sold, and transported. The Constitution protects the free movement of all of these articles of commerce against state-imposed economically motivated impediments. ${ }^{41}$

The commerce clause, the Court has written, forbids Pennsylvania to hoard its coal, the mining states their minerals, or the Northwest its timber. ${ }^{2}$ States that seek to imprison their industry are engaged in essentially the same behavior as states trying to husband their resources. They share an impermissible goal: to insulate a unique resource from the operation of the national market.

Indeed, the Court's hostility to embargo statutes is so strong that in the most recent case the Court struck down an Alaska statute controlling the export of timber despite respondent's argument that the challenged regulations fell within the Court's "market participation exception" to the commerce clause. South-Central Timber Dev. v. Wunnicke, 467 U.S. 82 (1984); see infra notes 76-81 and accompanying text.

38. City of Philadelphia, 437 U.S. at 624. Here, the Court invalidated a New Jersey statute prohibiting the importation of solid waste from neighboring Pennsylvania despite New Jersey's logical claim to be regulating public health. This result attests to the Court's firm conviction that embargo statutes are irreconcilably opposed to the principles of the commerce clause and should at a minimum be subjected to strict scrutiny.

39. Id. at 628 .

40. Id. at 627. The impermissibility of protectionism extends to means as well as ends.

41. At one time, the Court exempted natural resources from commerce clause scrutiny on the theory that states "owned" these resources. See Geer v. Connecticut, 161 U.S. 519 (1896). But this fiction of ownership suffered serious erosion not long after its original promulgation. See West v. Kansas Natural Gas, 221 U.S. 229 (1911); Pennsylvania v. West Virginia, 262 U.S. 553 (1933). It was finally repudiated in Hughes v. Oklahoma, 441 U.S. 322 (1978); see also Hicklin v. Orbeck, 437 U.S. 518 (1978) (striking down Alaska statute mandating that all Alaska oil and gas leases contain clause giving state residents preference in hiring). Although Hicklin was decided on privileges and immunities grounds, the Court explicitly drew support for its holding from commerce clause cases involving natural resources. As the Court emphasized, both the privileges and immunities clause and the commerce clause circumscribe a state's ability to prefer its own citizens. Together, the two clauses were meant to give full expression to the decidedly national vision embodied in Article IV of the Articles of Coniederation:

"The better to secure and perpetuate mutual friendship and intercourse among the people of different states of this union, the free inhabitants of each of these states. . . shall have free ingress and regress to and from any other state, and shall enjoy therein all the privileges of trade and commerce, subject to the same duties, impositions, and restrictions as the inhabitants thereof respectively; provided that such restriction shall not extend so far as to prevent the removal of property, imported into any state, to any other state in which the owner is an inhabitant."

Hicklin, 437 U.S. at 532 n.16.

42. Pennsylvania, 262 U.S. at 599-600; West, 221 U.S. at 255. 
Taken together, the capture and embargo cases reflect the Court's hostility towards state laws that in purpose or in primary effect ensnare or hoard economic benefits at the expense of out-of-state interests. ${ }^{13} \mathrm{~A}$ host of other cases, such as those striking down regulations obstructing the interstate movement of trucks ${ }^{44}$ or controlling the importation of produce or other food products, ${ }^{48}$ further highlight the strict scrutiny which the Court has applied to state statutes that disproportionately affect out-of-state interests. ${ }^{48}$ When a protectionist purpose is coupled with discriminatory means, the Court's careful scrutiny rises to the level of uniform rejection of the challenged statute. ${ }^{47}$

\section{The Inadequacy of Just Compensation}

Proponents of protectionist condemnations, in particular several commentators on Oakland Raiders, ${ }^{48}$ argue that since condemnees will receive just compensation, this use of eminent domain either does not bur-

43. In Hunt v. Washington State Apple Advertising Comm'n, 432 U.S. 333 (1977) (striking down a North Carolina apple labelling law), the Court made plain that it would scrutinize the primary effect of challenged legislation and not rely on the state's alleged intent. See also Hughes v. Oklahoma, 441 U.S. 322, 336 (1978) (Court "not bound" to accept state's purported purpose). Rare indeed would be the law that could not be rationalized on some legitimate ground. $C f$. Craig v. Boren, 429 U.S. 190 (1976) (inadequacy of rational relation equal protection scrutiny).

44. See, e.g., Raymond Motor Transp. v. Rice, 434 U.S. 429 (1978) (striking down Wisconsin law regulating truck trailers). The Court took particular exception to the size limit that discriminated in favor of the local truckers. See also Kassel v. Consolidated Freightways Corp., 450 U.S. 662 (1981) (invalidating Iowa truck length limits because local regulations bore disproportionately on out-of-state interests); South Carolina Highway Dep't v. Barnwell Bros., 303 U.S. 177, 185 n.2 (1938) ("Underlying the stated rule has been the thought . . . that when the regulation is of such a character that its burden falls principally upon those without the state, legislative action is not likely to be subjected to those political constraints which are normally exerted on legislation where it affects adversely some interests within the state.").

45. Hunt v. Washington Apple Advertising Comm'n, 432 U.S. 333 (1977).

46. While the Court has recognized that "incidental burdens on interstate commerce may be unavoidable when a state legislates to safeguard the health and safety of its people," City of Philadelphia, 437 U.S. at 623-24, the Court has carefully circumscribed what state interests justify discriminatory regulations. The Court has explicitly rejected the legitimacy of the local interests involved in protectionist condemnations. To allow economic regulation or the preservation of jobs as a necessary protection of local health or safety "would be to eat up the rule under the guise of an exception. Economic welfare is always related to health, for there can be no health if men are starving." Baldwin v. G.A.F. Seelig, 294 U.S. 511, 523 (1935).

47. The Court's efforts to reach some consensus about exactly what state behavior is objectionable under the commerce clause calls to mind the proverbial blind men examining the elephant. Some opinions focus on intent. See, e.g., Dean Milk Co. v. Madison, 340 U.S. 349 (1951). Others focus on means. See, e.g., City of Philadelphia, 437 U.S. at 617. Still others focus on effect. See, e.g., Pike, 397 U.S. 137. But see Regan, supra note 25, at 1209-33 (purpose inquiry definitive in movement-ofgoods cases). Regardless, the condemnation of relocating businesses would combine all of the parochial features that, in one strand of cases or another, the Court has found to be fundamentally inconsistent with the commerce clause.

48. See, e.g., The Next Step, supra note 8 (supporting the condemnation of industrial plants on the verge of relocation); see also Note, The Constitutionality of Taking a Sports Franchise by Eminent Domain, 13 FordhaM URB. L.J. 553 (1985) (suggesting federal legislation to regulate sports relocation). 
den interstate commerce or does so in a permissible fashion. ${ }^{49}$ They would distinguish condemnations from the regulations in Pike, Toomer, and Foster-Fountain, because in those latter cases the challenged state action "prevented out-of-state labor from competing with local labor. . . . [T]he statutes offered a simple choice between conducting a business activity within the state or being faced with a significant financial hardship. Such a choice does not simply burden commerce it blocks it."\$o

Eminent domain, they assert, meets the Pike test because the payment of just compensation, permitting the owner to continue operations out of state, "does no harm to out-of-state interests." tions, they conclude, are thus evenhanded and their burden on commerce negligible or incidental.

Both empirically and as a theoretical matter, however, just compensation does not transform the economic parochialism of protectionist condemnations into a permissible hindrance on the operation of the national market. Although the underlying purpose of just compensation is to "make the person whole," just compensation is not full compensation. . $^{\mathbf{2}}$ As presently defined, just compensation is based on the fair market value of the taken property. But, as the Court admits, the "relatively objective working rule" of fair market value_-"what a willing buyer would pay in cash to a willing seller"-does not necessarily (or even usually) compensate for all values an owner may derive from a property. ${ }^{.3}$

More specifically, in determining fair market value, the Court has

49. The Next Step, supra note 8, at 126.

50. Id. at 125 (citations omitted)

51. Much has been written not only about whether present compensation doctrine is "just," but also about whether a just valuation is a theoretical possibility. See, e.g., Michelman, Property, Utility, and Fairness: Comments on the Ethical Foundations of Just Compensation Law, 80 HaRv. L. Rev. 1165 (1967); Sax, Takings, Private Property and Public Rights, 81 Yale L.J. 149 (1971). For a recent consideration, see R. EPSTEIN, supra note 3, at 182-86 (1985) ("The central difficulty of the market formula . . . is that it denies any compensation for real but subjective values.").

One frequently proposed justification for allowing what in effect is undercompensation to the condemnee has as its central premise the belief that the condemnee receives a share of the "public good" for which his property was taken. But this public goods benefit, making up the difference between fair market value and the actual value to the owner, would not accrue to the owner of a relocating business. See Kimball Laundry Co. v. United States, 338 U.S. 1, 5 (1949) ("In view . . . of the liability of all property to condemnation for the common good, loss to the owner of nontransferable values deriving from his unique need for property or idiosyncratic attachment to it . . . is properly treated as part of the burden of common citizenship.").

52. See United States v. 564.54 Acres of Land, 441 U.S. 506, 510-11 (1978) (Indemnity principle, which would place the owner "in as good a position pecuniarily as if his property had not been taken ... has not been given its full and literal force.") (citations omitted).

53. Id.; see also United States v. Cors, 337 U.S. 325 (1949) (fair market value for condemned tugboat reduced so that price did not reflect increased wartime demand). When no ready market price exists, as may well be the case with protectionist condemnations (What is the fair market value of a sted mill?), most commentators agree that the courts consistently underestimate the value of condemned property. See, e.g., Note, Taking the Oakland Raiders: A Theoretical Reconsideration of the Concepts of Public Use and Just Compensation, 32 EMORY L.J. 857 (1983). 
found many of the property values and transaction costs which protectionist condemnations would involve-including loss of business profits, ${ }^{54}$ loss of opportunity ${ }^{55}$ litigation expenses ${ }^{56}$ or the frustration of an owner's plans $^{37}$ - to be non-compensable. ${ }^{58}$ The Court has made no attempt to establish, and, in fact, has explicitly rejected, a replacement cost compensation standard. ${ }^{88}$

The special nature of the assets subject to condemnation and the type of business likely to be condemned, make the payment of compensation particularly inadequate to remedy the constitutional defects of protectionist condemnations. Contracts, franchise rights, and licenses, necessary elements of protectionist takings, are unique commodities-not fungible with cash or replaceable at will. ${ }^{80}$ Stripped of these unique incorporeal rights, owners will be unable to replace their businesses or will be able to replace them only after substantial delay. ${ }^{81}$ In these cases, monetary compensation to the condemnee will not make whole communities that were to be the sites of relocations or undo the effect on the geographic distribution of American business. ${ }^{62}$

Even if the uniqueness of the condemned assets did not hinder relocation, in the high fixed-cost and limited demand industries most likely to be the subjects of condemnation, ${ }^{63}$ the presence of an additional competitor (the now state-owned plant) will make reinvestment in a new plant riskier and more expensive. Rather than compete in a tighter market, some own-

54. See Omnia Commercial Co. v. United States, 261 U.S. 502 (1923); Bothwell v. United States, 254 U.S. 231 (1920).

55. See United States v. Petty Motor Co., 327 U.S. 372 (1946); Mitchell v. United States, 267 U.S. 341 (1925).

56. See Note, Attorneys' Fees in Condemnation Proceedings, 20 Hastings L.J. 694 (1969).

57. United States v. Miller, 317 U.S. 369 (1943).

58. United States v. 564.54 Acres of Land, 441 U.S. 506, 511 (1978). Claims for consequential or incidental damages have routinely been rejected by the Court on the grounds that the costs are too speculative or that they confuse the nature of the state's obligation. At bottom, the Court has adopted a principle that the state must pay for what it receives, not for what the owner loses.

59. Id. at 512 .

60. As the organizers of proposed condemnations admit, the economic viability of the condemned tangible property depends on the ability to seize intangibles such as customer contracts. See B. BLuESTONe \& B. HARRISON, The Deindustrialization of AMERICA (1982); see also Kimball Laundry Co. v. United States, 338 U.S. 1, 16-17 (1949) (emphasizing difficulty of replacing or appraising customer goodwill); Boston Globe, Mar. 9, 1986, at 40, col. 2 (control of marketing label critical to proposed plant condemnation).

61. Had Baltimore succeeded in its eminent domain action against the Colts, regardless of the compensation paid, Indianapolis would have been without an NFL franchise.

62. Ironically, protectionist condemnations intended to preserve America's basic industries might actually provide a disincentive to prospective capital investment in industrial revitalization and development. Private owners, fearing public takeovers, might be reluctant to make large investments, given the risk of receiving inadequate compensation after condemnation.

63. Although in theory any business is subject to condemnation, in practice communities would condemn businesses that are expensive and impractical to start up. As the existing record of threatened condemnations indicates, the principal targets will be firms that are large community employers with significant physical plants. See infra notes 8-10 and accompanying text. 
ers will not re-invest in new plants, thereby depriving out-of-state communities of employment and other benefits that would otherwise have accrued to them.

The payment of compensation to the owner, at least as currently defined, does not change the fact that the arrangement of American business would be very different in a world with protectionist condemnations than in a world without them. Out-of-state plants that would otherwise have been built will cost too much to build. Employment opportunities that would have moved out of state will remain in state. Indeed, that is the very purpose of these takings: to impede the free flow of business and jobs. To the extent that protectionist condemnations succeed, they are antithetical to the commerce clause.

In sum, though current compensation schemes may reduce the burden caused by these takings, the condemnation of relocating businesses will still be animated by protectionist motives, will still affect the free movement of business to the exclusive detriment of out-of-state interests, and will still serve to isolate individual states from the national economic community. As the Court underscored in Pike, what makes a burden to commerce impermissible is its nature, not its size. ${ }^{64}$ Protectionist takings will remain direct manipulations of the economy subject to the Court's per se rule against such burdening of interstate commerce. ${ }^{60}$

Admittedly, the Court could, as a theoretical matter, adjust its compensation doctrine to provide "full" compensation to the condemnee, ${ }^{66}$ but only a compensation scheme that would leave unimpeded the free movement of business nationwide ${ }^{67}$ would satisfy the commerce clause interest

64. Pike, 397 U.S. at 142. See also Regan, supra note 25, at 1209-33 (protectionist purpose triggers invalidation). In any case, because of the unique assets involved in protectionist condemnations, even a "small" burden to commerce would, as an established practice, significantly alter the geographic distribution of industry across the country.

65. The necessary fiction that condemnees receive just compensation cannot be stretched so far as to obscure the fact that these takings unconstitutionally burden commerce. That some approximation of fair market value has been judicially determined to satisfy the requirements of the taking clause does not exempt condemnations from scrutiny under other constitutional provisions. For example, a municipality could not establish a segregated neighborhood by condemning property and paying compensation to minority owners, present and future. Cf. Shelley v. Kraemer, 334 U.S. 1 (1948) (refusing to enforce racial covenants). "[I]t would appear beyond question that the power of the state to create and enforce property interests must be exercised within the boundaries defined by the Fourteenth Amendment." Id. at 22 (citation omitted). Just compensation cannot cover a multitude of constitutional sins.

66. The Court might define full compensation in several ways, such as replacement cost in the original home state or replacement cost in the state of intended relocation, but these revised standards would pose thorny, if not intractable, valuation problems. Indeed, the current compensation doctrine, adhering closely to fair market value, in large part reflects the judiciary's recognition that it could not accurately apply a full compensation standard. See, e.g., United States v. 564.54 Acres of Land, 441 U.S. 506, 511 (1978).

67. This notion of free movement has deep constitutional roots not only in the commerce clause, but also in the privileges and immunities clause and, more generally in the very nature of federalism. Courts and commentators alike have recognized that the free transfer of allegiance among fifty com- 
in preventing economic balkanization. A compensation scheme in which the condemnee received the value of the condemned business in the location at which that business would be most highly valued, would pass constitutional muster. Such a scheme would simulate an auction among all interested communities, each bidding to be the site of the condemned firm, or, in other words, would make the "stick" of condemnation essentially identical to the constitutionally permissible "carrots"- subsidies and other inducements - that states already employ. ${ }^{68}$

\section{The Commerce Clause and local Authority}

The most compelling argument for allowing protectionist condemnations focuses on the community values that are jeopardized by industrial flight. Letting private owners determine business location often has disastrous consequences for the communities that fall victim to industrial dislocation. ${ }^{68}$ Translating this appeal into legal and economic terms, the authors of the burgeoning literature championing community rights ${ }^{70}$ claim

peting jurisdictions is a vital and considered feature of our constitutional system. See, e.g., Zobel v. Williams, 457 U.S. 55, 67-8 (1982) (Brennan, J., concurring) ("A State clearly may undertake to enhance the advantages of industry, economy, and resources that make it a desirable place in which to live. . . . That is a healthy form of rivalry: It inheres in the very idea of maintaining the States as independent sovereigns within an independent framework, and it is fully-indeed, necessarily-consistent with the Framers' further idea of joining these independent sovereigns into a single Nation."); Regan, supra note 25, at 1114 ([P]rotectionism takes over a market share by force; it is like acquiring territory by armed conquest. [Inducements] . . . use[] no force; [they] encourage[] a free transfer of allegiance. It is like acquiring territory by plebescite of the inhabitants."); see also New State Ice Co. v. Liebmann, 285 U.S. 262, 311 (1932) (Brandeis, J., dissenting) (each state free to try novel economic experiments without risk to rest of country); J. ELY, supra note 33, at 178-79 (right to travel critical to process-based constitutional theory).

68. If a state had to pay a condemnee the value of his business in the location where it would receive the highest valuation, a state would invoke eminent domain only in those cases in which the value of the business when located in state plus the value to the state of having the business in state exceeded the sum of those same values in every other location. In other words, a state would condemn only on those occasions when, in any event, the state would have triumphed in a bidding war. Given the high transaction costs associated with condemnation proceedings (such as valuation costs and attorneys fees), bribing an owner to remain in state would be equally effective and probably less expensive than condemning the business.

One danger in allowing unrestricted competition for business location is that private owners, at least in theory, can appropriate the entire value of the positive externality generated by the presence of a firm in a given locale. See infra note 91 . That competition among states for business location may produce undesirable distributional consequences does not, however, argue in favor of protectionist condemnations. The national legislature retains the power to regulate this economic competition-and, indeed, in a perverse way, the redistributional effects of the free competition for business location may make congressional action more likely than it would be in a world in which states could soften the impact of the inevitable redistribution of domestic industry.

69. See The Next Step, supra note 8, at 97-100. The effects of a plant closing on community life cannot be gainsaid. In addition to the obvious impact on local employment and revenue, the loss of a major employer often robs a community of its social cohesion.

70. See, e.g., B. Bluestone \& B. Harrison, supra note 64, at 231-64. For a taste of the community rights literature's treatment of other legal questions, see Sandman \& Leonard, Getting to Maybe: Some Communications Aspects of Siting Hazardous Waste Facilities, 9 SETON HALL. LEG. J. 437 (1986); Sax, Do Communities Have Rights? The National Parks as a Laboratory of New Ideas, 
that since private owners do not necessarily promote market efficiency when choosing business locations, municipal or state authorities should have the power to take relocating businesses. Although this literature may be attractive to a critic of American business practice, it fails to answer, or answers incorrectly, the critical question: If business relocation should be controlled, who should do the controlling?

\section{A. Federalism and the Commerce Clause}

Proponents of protectionist condemnations borrow a significant part of their legal rationale from traditional federalism arguments in favor of judicial deference to local decision makers. ${ }^{71}$ Their theory is simple: Eminent domain is a peculiarly local power, "an inherent attribute of sovereignty,"72 and an area in which the courts have shown special deference to local legislative authority. ${ }^{73}$ The dormant commerce clause, one of the "great silences of the Constitution," "74 therefore, should not be read broadly to trench upon this core element of local governance. ${ }^{75}$

In the context of interstate commerce, the argument for deference is unpersuasive. Although the Court has recognized that federalism concerns are sufficiently strong to create an exception to the commerce clause in the singular instance when a state affects interstate commerce while acting as a market participant, ${ }^{78}$ the Court has frequently observed that the com-

45 U. PrTT. L. Rev. 499 (1984).

71. See R. Epstein, supra note 3, at 161; City of Oakland v. Oakland Raiders, 174 Cal. App. 3d 414, 220 Cal. Rptr. 153 (1985).

72. City of Oakland v. Oakland Raiders, 32 Cal. 3d 60, 64, 646 P.2d 835, 837, 183 Cal. Rptr 673, 676 (1982) (quoting County of San Mateo v. Coburn, 130 Cal. 631, 634, 63 P. 78, 79 (1900)).

73. See Hawaii Hous. Auth. v. Midkiff, 467 U.S. 229, 241 (1984) ("Where the exercise of the eminent domain power is rationally related to a conceivable public purpose, the Court has never held a compensated taking to be proscribed by the Public Use Clause."); see also Poletown Neighborhood Council v. City of Detroit, 410 Mich. 616, 634, 304 N.W.2d 454, 458-59 (1981) (upholding condemnation of neighborhood to provide site for new auto plant).

74. H.P. Hood \& Sons v. Du Mond, 336 U.S. 525, 535 (1949).

75. As the City of Oakland argued in Oakland Raiders, no court (prior to the ruling in that case) had ever invalidated an exercise of local eminent domain power on commerce clause grounds. Oakland Raiders, $174 \mathrm{Cal}$. App. 3d at 419, $220 \mathrm{Cal}$. Rptr. at 156. This absence of precedent, however, does not reflect the inapplicability of the commerce clause doctrine to local takings, but rather the fact that the commerce clause has only become relevant as a result of the recent relaxation of other constitutional limits on the taking power.

In at least one state case, a court upheld a local taking in the face of a commerce clause challenge. See Elberton S. Ry. Co. v. State Highway Dep't, 211 Ga. 838, 89 S.E.2d 645 (1955) (upholding state use of eminent domain over railroad right-of-way). Elberton is not controlling. It fits into the incidental burdening allowance under the Pike balancing test and does not fall under the per se rule of invalidity. See infra notes 19-27 and accompanying text.

76. See Hughes v. Alexandria Scrap Co., 426 U.S. 794 (1976). Alexandria Scrap involved a statute that mandated the payment of a bounty to companies that processed car hulks in state. The majority emphasized that, although the challenged statute discriminated against out-of-state businesses, the business of destroying old cars was in essence state-created, and therefore exempt from the usual commerce clause limits. The crux of the market participation cases is the state's assumption of a completely private proprietary role. It is precisely because the state is not exercising an exclusively 
merce clause explicitly allocates power to the federal government in derogation of the states. ${ }^{77}$ As the Court has noted, of all state powers surrendered upon the adoption of the Constitution, the power over commerce was that most thoroughly surrendered. ${ }^{28}$

Despite the "states' rights" dicta in some of the market participation cases ${ }^{79}$ nothing in the market participation doctrine reworks the heavy burden against state interests reflected in traditional dormant commerce clause jurisprudence. ${ }^{80}$ The market participation cases, though bottomed on federalism principles, create a narrow exception to normal commerce clause scrutiny for those cases in which a state, participating in the marketplace, sheds its sovereign persona and adopts an essentially private persona-with all of the freedoms and limitations that adhere to private owners. ${ }^{81}$ Protectionist condemnations not only fail to qualify for the market

sovereign power that the state action is exempt from commerce clause scrutiny. See South-Central Timber Dev. v. Wunnicke, 467 U.S. 82 (1984) (limiting scope of market participation exception); see also White v. Massachusetts Council of Constr. Employers, 460 U.S. 204 (1983) (upholding Boston mayoral order that all city-funded construction projects be performed by work force consisting of at least 50\% city residents); Reeves Inc. v. Stake, 447 U.S. 429 (1980) (upholding policy of South Dakota-owned and operated cement plant requiring supply of all in-state customers before any outof-state customers). For a good analysis of the market participation cases, see Note, The Market Participant Test in Dormant Commerce Clause Analysis-Protecting Protectionism?, 1985 DukE L.J. 697.

77. See, e.g., Hughes v. Oklahoma, 441 U.S. 322, 325-26 (1978).

78. "No other federal power was so universally assumed to be necessary" to the preservation of the union. H.P. Hood \& Sons v. Du Mond, 336 U.S. 525, 534 (1949).

79. The market participation cases are laced with the language of federalism and judicial restraint: "To stay experimentation in things social and economic is a grave responsibility. . . . It is one of the happy incidents of the federal system that a single courageous State may, if its citizens choose, serve as a laboratory; and try novel social and economic experiments without risk to the rest of the country." Reeves Inc., 447 U.S. at 441 (quoting New State Ice Co. v. Liebmann, 285 U.S. 262, 311 (1932) (Brandeis, J. dissenting)).

It is no accident that the first market participation case, Alexandria Scrap, 426 U.S. at 794, was decided immediately prior to National League of Cities v. Usery, 426 U.S. 833 (1976), the first case since the New Deal placing important limits on the affirmative federal power to regulate interstate commerce. The idea of core state functions ("states qua states") is a central force behind both cases and may be more forceful in the dormant commerce clause context in which prohibitions on state action are derived from silence. In Garcia v. San Antonio Metro. Transit Auth., 469 U.S. 528 (1985), the Court overruled National League of Cities. Whether the market participation cases will prove much more durable than National League of Cities is as yet unclear.

80. The market participation exception exempts only state "proprietary" action from commerce clause scrutiny. In exercising the sovereign power of eminent domain over relocating businesses, local authorities will be deliberately circumventing the market process, not participating in it. See Oakland Raiders, 174 Cal. App. 3d at 419, 220 Cal. Rptr. at 156.

81. See Alexandria Scrap, 426 U.S. at 810 ("Nothing in the purpose animating the Commerce Clause prohibits a State, in the absence of Congressional action, from participating in the market and exercising the right to favor its own citizens over others."). Actually, the term "market participant" is something of a misnomer. The exception to commerce clause scrutiny also applies to cases in which a state provides subsidies that disproportionately favor in-state enterprises. Id. (upholding subsidy favoring in-state auto scrap companies). Subsidies are readily distinguishable from protectionist condemnations. Although subsidy programs may disproportionately distribute newly state-created economic opportunitics to local firms, they do not prevent out-of-state businesses from participating in economic activity that the state itself has not generated. Moreover, to the extent that subsidies may create cconomic inefficiencies (notably, the risk here is overproduction, not underproduction), the adverse conse- 
participation exception, they draw little if any constitutional sustenance from the exception's existence.

Nor can eminent domain be immunized from commerce clause scrutiny because it is an inherent aspect of state or local sovereignty. ${ }^{\mathbf{8 2}}$ While it may be that traditional uses of the eminent domain power, uses closely associated with land use regulation, are quintessentially local concerns, ${ }^{83}$ the appropriation of contracts, franchise rights, and other commercial intangibles attached to relocating businesses are not peculiarly local. The ability to take these commercial properties into the stream of interstate commerce makes them transient and removes them from the realm of exclusive local control. ${ }^{84}$

quences of the subsidy will be borne by the subsidizing state, not by unrepresented out-of-state interests. See Levmore, supra note 12 , at $570-75$.

82. The power of eminent domain does not derive from the Constitution; rather, it is based upon the principle, borrowed from Europe, that absolute ownership of property originated at all times with the state, and thus all personal rights to property may be extinguished by the state at any time. 1 Nichots, supra note 3 , at $\S 1.13$.

83. Even under the Court's broad definition of a constitutionally permissible public use, the most innovative uses of eminent domain have, with few exceptions, been limited to land use regulation. See, e.g., Berman v. Parker, 348 U.S. 26 (1954) (upholding use of eminent domain for urban renewal). Notably, the Court has not hesitated to apply rigorous dormant commerce clause analysis to matters of special local concern or competence. Although in South Carolina State Highway Dep't v. Barnwell Bros., 303 U.S. 177, 187 (1937) (upholding local highway regulation), the Court noted that "[f]ew subjects of state regulation are so peculiarly of local concern as is the use of state highways," the Court has on several occasions invalidated highway regulations that disproportionately burdened outof-state interests. See, e.g., Kassel v. Consol. Freightways Corp., 450 U.S. 662 (1981) (striking down Iowa limit on truck length); Raymond Motor Transp. v. Rice, 434 U.S. 429 (1978) (striking down Wisconsin ban on trucks longer than 55 feet).

84. The law of eminent domain makes no distinction between real and personal property or between tangible and intangible property. Although the condemnation of intangibles and other property without fixed situs raises difficult jurisdictional questions, all types of property are subject to condemnation. But for the purposes of the commerce clause, a distinction between movable and fixed property might be appropriate. Local competence over many types of movable property is problematic. Contracts, patents, franchises, and other commercial interests are often not state created. Many commercial intangibles are federally created and may not be subject to state regulation. Even the right to incorporate has, according to the Court, "ceased to be a privilege to be dispensed by the state as it sees fit . . . [but rather must be] generally available to all on equal terms." Western \& Southern Life Ins. Co. v. State Bd. of Equalization, 451 U.S. 648, 660 (1981).

The notion that the exercise of local authority over land is qualitatively different than local authority over transient property is a long standing principle of jurisdiction law. See, e.g., Shaffer v. Heitner, 433 U.S. 186 (1977) (stock certificates located outside state insufficient "contact" for assumption of jurisdiction). In Edgar v. Mite, 457 U.S. 624 (1982) (commerce clause case striking down Illinois' anti-takeover statute), the Court itself drew the parallel between the limits on state jurisdictional power over intangible property lacking sufficient contacts with the state and state power to enact substantive legislation involving property located outside of the state: "In either case," the Court held, " "any attempt directly to assert extraterritorial jurisdiction over persons or property would offend sister States and exceed the inherent limits on the State's power." Id. at 643 (quoting Shaffer v. Heitner, 433 U.S. 186, 197 (1977).

The Colts case again illustrates the point. However the jurisdictional question would ultimately have been resolved in court, it seems apparent that the condemnation of intangible property-property that defies territorial bounds-lies not at the core of state power, but somewhere near the outer boundary. 


\section{B. Local Competence}

Those who argue that the commerce clause should not impinge on local eminent domain power not only fail to recognize the national implications of local takings, they also overestimate the legal and practical competence of local authorities to create or effect national industrial policy. Although advocates of protectionist condemnations assert that local authorities will make more efficient choices for plant location than will private owners, a discussion of the externalities involved in business relocation belies their reasoning.

Admittedly, in making a business decision, the relocating owner might not consider the cost to a community. ${ }^{85}$ Local authorities, however, also do not account for the full range of externalities. Just as the owner acts solely in his own interest, the community acts in its interest. Although the community may account for the owner's interest by paying compensation, neither owner nor community considers out-of-state or national interests-the interests with which the framers of the Constitution were preoccupied. $^{86}$

This inherent parochialism in local regulation of economic activity is, as noted above, the very evil at which dormant commerce clause jurisprudence takes aim. But even the law of land use, the peculiar province of local authorities, recognizes, in at least one reknowned case, that the judiciary must prevent local governments from overreaching their competence at the expense of unrepresented interests. As Justice Hall observed in the landmark exclusionary zoning case Southern Burlington County NAACP v. Township of Mt. Laurel: ${ }^{87}$

Frequently decisions in this state . . have spoken only in terms of the interest of the enacting municipality, so that it has been thought, at least in some quarters, that such was the only welfare requiring consideration .... [But] when regulation does have a substantial external impact, the welfare of the state's citizens beyond the borders of the particular municipality cannot be disregarded and must be recognized and served." 88

85. If communities compete for business location, however, private owners, by moving to the location that offers them the best deal, will in fact account for community values. See supra note 68 and accompanying text.

86. See generally G. Black, Structure and Rel.ationship in Constitutional Law (1969) (suggesting structural reading of constitutional text). The paramount concept of nationhood does not take strength solely from the commerce clause. See U.S. CoNST. preamble; id. art. VI, cl.2 (supremacy clause); $i d$. art. IV, $\S 2$, cl.1 (privileges and immunities clause).

87. South Burlington County NAACP v. Township of Mount Laurel, 67 N.J. 151, 336 A.2d 713

(1975) (striking down local exclusionary zoning plan).

88. Id. at 177,336 A. $2 \mathrm{~d}$ at 726 . 
Local legislatures condemning businesses, no less than local zoning boards, simply are not competent and should not be allowed to wield local power to the detriment of outside interests. In the context of eminent domain, there is a limit on local authority implicit in the language of the Constitution. Takings must be for a "public use." That is their justification. But protectionist condemnations involve more than one public. If condemnations are required to be in the public interest, surely that should mean in the interest of the entire affected public, not merely that portion of the public represented by the enacting local legislature.

The ability to represent all of the interests involved in business relocation, not just those of communities that would insulate themselves from economic and demographic change, lies solely with the national legislature. Yet advocates of protectionist condemnations argue that Congress will not enact meaningful legislation in the area of industrial policy. ${ }^{89}$ In the absence of congressional action, they assert, the courts should allow local communities to protect themselves from the consequences of industrial dislocation.

But that Congress has not created an explicit national industrial policy regarding business location, ${ }^{80}$ does not mean that state sponsored protectionism for local industries should be considered either good policy or constitutionally permissible. In the absence of congressional action, states should compete for business location. ${ }^{81}$

89. See, e.g., F. Rohatyn, The Twenty Year Gentury 15 (1983) (American system lacks mechanism to articulate common purposes, mobilize majoritarian power, and check special interest group pressure).

90. Congressional silence does not necessarily denote an absence of policy.

91. That free interstate competition for business is both desirable and preferable to a market undermined by protectionist condemnations appears nicely from a simple model in which $\mathrm{L}_{m}$ stands for the value to Massachusetts of having a business in-state, and $K_{m}$ stands for the value of the business when located in Massachusetts. $L_{l}$ and $K_{l}$ stand for the same values with respect to Texas.

In a world without state competition for business, firms can be expected to locate wherever the firm is worth the most. In other words, business location will depend on whether $K_{m} \gtrless K_{t}$. This result takes no account of social costs-the values represented by $\mathrm{L}_{m}$ and $\mathrm{L}_{\mathrm{l}}$.

In contrast, in the efficient situation, a business would settle wherever the value of the business to the state plus the value of the business in that state is greatest. Symbolically, the efficient location depends on whether:

(1) $\mathrm{K}_{\mathrm{m}}+\mathrm{L}_{\mathrm{m}} \gtreqless \mathrm{K}_{\mathrm{t}}+\mathrm{L}_{\mathrm{t}}$.

In a world in which protectionist condemnatians were permitted, a state would have incentives to condemn a relocating business anytime that keeping the business would capture a positive externality. In other words, whenever

(2) $\mathrm{K}_{\mathrm{m}}+\mathrm{L}_{\mathrm{m}}>\mathrm{K}_{\mathrm{m}}$

Massachusetts will have an incentive to condemn. Thus if protectionist condemnations are permitted, Massachusetts would never take account of the value of the business to Texas or the greater value the business might achieve if it moved $\left(L_{t}\right.$ and $\left.K_{t}\right)$.

On the other hand, if the two states compete for the business, through subsidies such as tax abatements, each state will have incentives to offer the private owner an amount up to the total value of the business itself $\left(\mathrm{K}_{\mathrm{m}}+\mathrm{L}_{\mathrm{m}}\right.$ or $\mathrm{K}_{\mathrm{l}}+\mathrm{L}_{\mathrm{t}}$ ). The result of this competition will accord precisely with the definition of efficiency. In a world in which states and localities act on incentives, business location will depend on whether: 
When local legislatures usurp Congress' power to shape the national economy, the courts should strike their actions down. Fairness to unrepresented interests dictates that it should be so and, more important, the Constitution requires it.

(1) $K_{m}+L_{m} \gtrless K_{1}+L_{l}$. 